\title{
PENGGUNAAN BAKTERI PROBIOTIK DENGAN KOMPOSISI BERBEDA UNTUK PERBAIKAN KUALITAS AIR DAN SINTASAN PASCALARVA UDANG WINDU
}

\author{
Muharijadi Atmomarsono, Muliani, dan Nurbaya \\ Balai Riset Perikanan Budidaya Air Payau \\ Jl. Makmur Dg. Sitakka, Maros, Sulawesi Selatan 90511 \\ E-mail: hari_atm@yahoo.co.id
}

Naskah diterima: 3 Januari 2009; Diterima publikasi: 2 April 2009

\begin{abstract}
ABSTRAK
Penelitian ini bertujuan untuk mengetahui pengaruh komposisi jenis bakteri probiotik terhadap perbaikan kualitas air dan sintasan pascalarva udang windu pada skala laboratorium. Rancangan acak lengkap (RAL) dengan menggunakan 24 akuarium yang masing-masing diisi $10 \mathrm{~L}$ air bersalinitas 28 ppt dan 200 ekor benur windu PL-15 telah diaplikasikan pada percobaan di Laboratorium Balai Riset Perikanan Budidaya Air Payau (BRPBAP) Maros. Delapan perlakuan yang dicobakan adalah A) Bakteri probiotik asal laut (BL536+BL542+BL548); B) Bakteri asal mangrove (PK446+BR883+BR931+MY1112); C) Bakteri probiotik asal tambak (MR55+BT950+BT951+PR1080+BN2067); D) Bakteri laut+mangrove; E) Bakteri laut+tambak; F) Bakteri mangrove+tambak; G) Bakteri laut+mangrove+tambak; H) Kontrol (tanpa bakteri probiotik). Masing-masing perlakuan diulang tiga kali. Setelah 96 jam aplikasi didapatkan bahwa kombinasi bakteri probiotik asal mangrove dan tambak mampu mengendalikan kandungan bahan organik secara signifikan $(P<0,05)$. Bakteri asal laut dan mangrove secara tunggal maupun kombinasinya dapat menekan peningkatan amoniak dalam air $(P>0,05)$. Walaupun konsentrasinya masih aman $(0,0136-0,0184 \mathrm{mg} / \mathrm{L})$, peningkatan kandungan nitrit kurang mampu dikendalikan oleh bakteri probiotik yang diaplikasikan $(P>0,05)$. Sintasan pascalarva udang windu pada perlakuan bakteri probiotik asal laut $(97,5 \%)$ nyata lebih tinggi $(P<0,05)$ daripada kontrol $(82,0 \%)$. Secara keseluruhan, peningkatan populasi bakteri Vibrio spp. dalam air telah menyebabkan menurunnya sintasan pascalarva udang windu $(r=-0,834 ; P<0,01)$.
\end{abstract}

KATA KUNCl: udang windu, probiotik, kualitas air, sintasan, v. harveyi

ABSTRACT: Use of different compositions of probiotic bacteria to improve water quality and survival rate of tiger shrimp postlarvae. By: Muharijadi Atmomarsono, Muliani, and Nurbaya

The objective of this study was to know the effect of different probiotic bacteria compositions on water quality improvement and survival rate of tiger shrimp postlarvae. This experiment was carried out in completely randomized design using 24 aquaria filled with $10 \mathrm{~L}$ of 28 ppt water and 200 pcs of tiger shrimp PL 15 at the RICA laboratory. Eight treatments tested here were $A)$ Sea bacteria (BL536+BL542+BL548); B) Mangrove bacteria (PK446+BR883+BR931+MY11112); C) Brackishwater pond bacteria (MR55+BT950+BT951+PR1080+BN2067); D) Bacteria of $A+B$; E) Bacteria of $A+C$; F) Bacteria of $B+C$; $G$ ) Bacteria of $A+B+C$; and $H$ ) Control (without probiotic bacteria). After 96-h of application, the results showed that the combination of probiotic bacteria from brackishwater pond and mangrove (treatment F) were able to decrease total organic matter in the water media significantly $(P<0.05)$. 
Probiotic bacteria either from the sea (A), from mangrove (B), or combination of these two sources $(D)$ are appropriate in controlling ammonia concentration $(P<0.05)$. Although nitrite concentrations in the water media are quite low $(0.0136--0.0184 \mathrm{mg} /$ $L)$, the increase of nitrite could not be controlled by any probiotic bacteria in this experiment. The survival rate of tiger shrimp postlarvae using sea source bacteria $(97.5 \%)$ was significantly higher $(P<0.05)$ than that of in control $(82.0 \%)$. There were inversely correlated $(r=-0.834 ; P<0.01)$ between population of Vibrio spp. and the survival rate of tiger shrimp postlarvae.

\section{KEYWORDS: probiotic bacteria, water quality, V. harveyi, survival rate, tiger shrimp}

\section{PENDAHULUAN}

Berbagai kasus kematian udang di tambak akibat serangan penyakit bakterial maupun viral masih sering terjadi hingga saat ini. Hal ini bukan hanya terjadi di Indonesia (Madeali et al., 1993; Atmomarsono, 2004; Muliani et al., 2004), namun juga terjadi di negara lain seperti Thailand (Chanratchakool et al., 1995; Rengpipat et al., 1998); Taiwan (Lo et al., 1997); Filipina (Albaladejo et al., 1998); India (Vaseeharan et al., 2003); Australia (Spann et al., 1995); Jepang (Itami et al., 1998; Kono et al., 2004); dan Amerika (Dhar et al., 2001).

Metode pencegahan dan penanggulangan penyakit pada udang windu dengan menggunakan obat-obatan dan antibiotik telah banyak dilakukan baik di dalam maupun di luar negeri (Chanratchakool et al., 1995). Meskipun metode ini cukup efektif, namun sangat tidak dianjurkan karena adanya bahaya residu obatobatan pada organisme budidaya. Beberapa jenis antibiotik yang sering digunakan dalam penanggulangan penyakit udang windu seperti chloramphenicol sudah dilarang oleh pemerintah. Pencegahan penyakit udang windu melalui pengelolaan limbah budidaya menggunakan tandon dan biofilter juga telah dirintis beberapa tahun lalu dan hingga sekarang masih terus dikembangkan untuk penyempurnaan aplikasinya (Atmomarsono et al., 1995; Chanratchakool et al., 1995; Muliani et al., 1998; Atmomarsono, 2000). Namun demikian, berbagai cara di atas masih belum menampakkan hasil yang memadai, mengingat masih banyak kasus penyakit udang di tambak. Oleh karena itu, perlu dicari alternatif lain dalam penanggulangan penyakit udang windu di tambak. Salah satu alternatif tersebut adalah pemanfaatan bakteri probiotik yang bersifat non patogen (Poernomo, 2004) dan memiliki kemampuan menghambat dan membunuh bakteri patogen, serta menghalangi komunikasi antar sel-sel bakteri agar tidak terjadi korum sensing yang dapat menyebabkan timbulnya sifat patogen. Bakteri probiotik juga diharapkan dapat berfungsi sebagai pengurai bahan organik dan penetralisir kualitas air, serta memungkinkan sebagai makanan bagi organisme perairan. Sumber bakteri probiotik yang telah diteliti di antaranya adalah air dan sedimen laut, karang, dan daun mangrove (Tjahyadi et al., 1994; Rosa et al., 1997; Hala, 1999; Haryanti et al., 2000; Muliani et al., 2004).

Beberapa keunggulan dalam penggunaan bakteri probiotik untuk penanggulangan penyakit udang antara lain 1) organisme yang digunakan telah dipertimbangkan lebih aman daripada berbagai bahan kimia; 2) tidak patogen terhadap ikan/udang; 3) tidak terakumulasi dalam rantai makanan; 4) adanya proses reproduksi yang dapat mengurangi pemakaian yang berulang; 5) jarang menimbulkan resistensi bagi organisme sasaran; 6) dapat digunakan secara bersamaan dengan cara proteksi yang lain.

Pemanfaatan bakteri probiotik lokal yang berasal dari laut, mangrove, dan tambak udang diharapkan dapat lebih efektif dalam mengatasi persoalan penyakit pada budidaya udang windu di tambak. Penelitian ini ditujukan untuk mengetahui pengaruh komposisi jenis bakteri probiotik terhadap perbaikan kualitas air dan sintasan pascalarva udang windu pada skala laboratorium.

\section{METODOLOGI}

Penelitian ini dilakukan pada skala laboratorium dengan menggunakan akuarium ukuran $35 \mathrm{~cm} \times 22 \mathrm{~cm} \times 28 \mathrm{~cm}$ yang diisi $10 \mathrm{~L}$ air tambak bersalinitas 28 ppt. Hewan uji yang digunakan berupa benur windu PL-15 sebanyak 200 ekor/wadah yang sebelumnya telah diskrining dengan formalin $200 \mathrm{mg} / \mathrm{L}$ secara perendaman selama 30 menit. Dua belas 
(12) isolat bakteri yang berasal dari laut, mangrove, dan tambak yang masing-masing telah teruji memiliki enzim pengurai bahan organik (uji biokimiawi secara "in vitro") serta memiliki kemampuan menghambat pertumbuhan Vibrio harveyi digunakan dalam penelitian ini.

Penelitian dilakukan dengan Rancangan Acak Lengkap (RAL) dengan delapan perlakuan, yaitu (A) Bakteri asal laut (BL536+BL542+ BL548); (B) Bakteri asal mangrove (filosfer) (PK446+BR883+BR931+MY1112); (C) Bakteri asal tambak (MR55+BT950+BT951+PR $1080+$ BN2067); (D) bakteri laut + bakteri mangrove; (E) Bakteri laut + bakteri tambak; (F) Bakteri mangrove + bakteri tambak; (G) Bakteri laut + bakteri mangrove + bakteri tambak; $(\mathrm{H})$ Kontrol (tanpa pemberian bakteri probiotik). Masingmasing perlakuan diulang tiga kali. Pengamatan total bakteri dan total Vibrio spp. pada wadah penelitian dilakukan setiap 24 jam selama 96 jam, sedangkan pengamatan kualitas air yang meliputi bahan organik total (BOT), amoniak $\left(\mathrm{NH}_{3}-\mathrm{N}\right)$, nitrit $\left(\mathrm{NO}_{2}-\mathrm{N}\right)$ dilakukan pada awal dan akhir penelitian. Penelitian ini dilakukan hanya dalam waktu 96 jam seperti dilakukan oleh Prayitno (1994) dalam melakukan uji patogenesitas bakteri Vibrio spp. terhadap larva udang windu dan juga yang dilakukan oleh Chin \& Chen (1987) dalam melakukan uji toksisitas amoniak terhadap larva udang windu. Selain itu, karena tujuan penelitian ini adalah untuk mengetahui pengaruh pemberian bakteri probiotik terhadap perubahan kualitas air dan sintasan pascalarva udang windu, sehingga selama penelitian berlangsung (96 jam) tidak dilakukan penggantian air, karena dapat mengganggu perlakuan yang diberikan.

Jumlah bakteri (total bacterial count) dalam air media pemeliharaan udang diamati dan dihitung tiap 24 jam selama 96 jam dengan cara menumbuhkan pada cawan petri berisi media Tryptic Soy Agar (TSA). Sedangkan jumlah Vibrio spp. dalam air media pemeliharaan diamati dan dihitung tiap 24 jam selama 96 jam dengan menggunakan cawan petri berisi Thiosulphate Citrate Bile Salt Sucrose Agar (TCBSA).

Persentase peningkatan ataupun penurunan mutu air akibat perlakuan diperhitungkan berdasarkan mutu air awalnya, yaitu merupakan rasio dari kandungan kualitas air (BOT, $\mathrm{NH}_{3}-\mathrm{N}$, atau $\mathrm{NO}_{2}-\mathrm{N}$ ) pada akhir penelitian dibagi dengan kandungannya pada awal penelitian dan dikalikan dengan seratus persen. Pengamatan sintasan pascalarva udang windu dilakukan pada akhir penelitian (96 jam). Sintasan pascalarva udang windu maupun perubahan mutu air media pemeliharaan pada akhir penelitian (96 jam) dianalisis ragamnya setelah dilakukan transformasi data (bila diperlukan). Dan diuji lanjut dengan uji wilayah ganda Duncan pada $\mathrm{P}<0,05$ untuk mengetahui perlakuan komposisi probiotik yang terbaik (Steel \& Torrie, 1995).

\section{HASIL DAN BAHASAN}

Mengingat bahwa berbagai kasus penyakit yang terjadi pada budidaya udang windu adalah dipicu oleh penurunan mutu air seperti meningkatnya kandungan bahan organik total, kandungan amoniak, dan kandungan nitrit, maka pembahasan mutu air dalam tulisan ini lebih diarahkan pada ketiga parameter tersebut. Panjaitan (1991) menyatakan, bahwa peningkatan kandungan bahan organik total merupakan pemicu kematian larva udang windu di panti pembenihan. Sedangkan Boyd (1990) melaporkan, bahwa daya racun nitrit yang ada dalam perairan sangat dipengaruhi oleh kandungan amoniaknya, di mana jika kandungan kedua faktor tersebut tinggi, maka secara bersama-sama keduanya merupakan pemicu stres pada udang dan ikan yang dibudidayakan, sehingga udang dan ikan lebih rentan terserang penyakit.

Pada Tabel 1 terlihat bahwa kandungan bahan organik total (BOT) pada akhir penelitian $(6,26-17,92 \mathrm{mg} / \mathrm{L})$ jauh lebih rendah dari pada awal penelitian, yaitu antara $20,9 \%-59,8 \%$ dari kandungan awalnya. Penurunan kandungan BOT yang terbesar $(79,1 \%)$ didapatkan pada perlakuan yang menggunakan kombinasi bakteri probiotik yang berasal dari mangrove dan tambak udang (perlakuan F). Penggunaan kombinasi bakteri probiotik ini terbukti mampu menurunkan kandungan bahan organik total $(P<0,05)$ lebih baik daripada kontrol. Hal ini dimungkinkan, karena pada perlakuan $F$ terdapat beberapa jenis bakteri, seperti Bacillus firmus, Brevibacillus laterosporus, Vibrio vulnificus, Serratia marcescens, dan Psychrobacter sp. yang memang memiliki kemampuan mengurai bahan organik. Sedangkan penggunaan kombinasi bakteri probiotik dari laut + mangrove + tambak udang (perlakuan G), walaupun mampu menurunkan kandungan bahan organik total hingga $75,3 \%$ daripada kandungan awalnya, penurunan tersebut tidak berbeda nyata $(P>0,05)$ dengan 
kontrol (61,5\%). Kombinasi bakteri yang berlebihan seperti pada perlakuan G ini ( 12 jenis bakteri) tidak selalu berpengaruh positif terhadap perbaikan kualitas air, bahkan ada kalanya dijumpai adanya satu dua spesies yang mungkin menghambat pertumbuhan bakteri yang lainnya. Dari pengujian secara in-vitro didapatkan, bahwa bakteri Serratia marcescens asal mangrove seringkali saling menghambat dengan pertumbuhan bakteri Pseudoalteromonas sp. asal laut. Jadi walaupun keduanya memiliki kemampuan menguraikan bahan organik, pertumbuhan keduanya saling menghambat. Oleh karena itu, kedua jenis bakteri tersebut sebaiknya tidak diaplikasikan secara bersamaan. Penurunan kandungan BOT yang terkecil terjadi pada perlakuan yang menggunakan probiotik yang berasal dari mangrove saja (perlakuan B), yaitu hanya sekitar $40,2 \%$ dari kandungan awalnya. Hal ini justru jauh lebih rendah $(P<0,05)$ daripada penurunan kandungan BOT yang terjadi pada semua perlakuan lainnya (temasuk pada kontrol). Hal ini dimungkinkan karena air yang digunakan pada semua perlakuan adalah air tambak yang sebelumnya tidak disterilkan, di mana di dalamnya juga terkandung beberapa jenis bakteri yang mampu menguraikan bahan organik. Adanya penambahan bakteri Kluyvera cryocrescens dari mangrove diduga merupakan penghambat aktivitas kerja bakteri asal tambak tersebut. Pada kondisi normal, air tambak mengandung jenis bakteri alami yang dapat berfungsi sebagai pengurai bahan organik apabila pH air, alkalinitas total, suhu, salinitas, dan kandungan oksigen terlarut memenuhi syarat untuk kehidupannya. Dalam hal ini Atmomarsono (1992) melaporkan, bahwa kandungan bahan organik dan alkalinitas total dapat digunakan sebagai faktor penduga kesuburan tambak. Hal ini karena bakteri pengurai bahan organik di tambak lebih aktif pada kondisi pH air agak basa (di atas 7,2), sedangkan kestabilan $\mathrm{pH}$ air sendiri dikontrol oleh nilai alkalinitasnya, di mana alkalinitas total air tambak yang direkomendasikan Atmomarsono (2004) adalah lebih tinggi dari $80 \mathrm{mg} / \mathrm{L} \mathrm{CaCO}_{3}$ equivalent.

Penurunan kandungan BOT yang terjadi pada penggunaan bakteri probiotik asal tambak udang yang dikombinasikan dengan bakteri asal mangrove (perlakuan F) adalah lebih baik daripada perlakuan lainnya. Hal ini diduga karena pada perlakuan tersebut selain mempunyai komposisi jenis bakteri yang lebih bervariasi, yaitu 9 jenis, juga bakteri probiotik tersebut relatif lebih mudah beradaptasi dengan air media pemeliharaan pascalarva udang windu yang menggunakan air tambak. Secara umum kandungan bahan organik total dalam air media pemeliharaan pascalarva udang windu pada semua perlakuan masih dalam kisaran yang layak untuk budidaya

Tabel 1. Perbaikan kandungan bahan organik total (BOT) dalam air media pemeliharaan pascalarva udang windu setelah 96 jam penggunaan komposisi bakteri probiotik berbeda

Table 1. Improvement of total organic matter concentration in tiger shrimp postlarvae culture media after 96 hour application of different compositions of probiotic bacteria

\begin{tabular}{|c|c|c|c|}
\hline $\begin{array}{c}\text { Komposisi bakteri probiotik } \\
\text { Probiotic bacteria compositions }\end{array}$ & $\begin{array}{c}\text { Kandungan BOT } \\
\text { akhir penelitian } \\
\text { Final concentration of } \\
\text { total organic matter } \\
(\mathrm{TOM})(\mathrm{mg} / \mathrm{L})\end{array}$ & $\begin{array}{l}\text { Persentase BОТ } \\
\text { dibanding awal } \\
\text { Percentage of final } \\
\text { to initial TOM (\%)* }\end{array}$ & $\begin{array}{c}\text { Penurunan bahan } \\
\text { organik total (BOT) } \\
\text { Total organic } \\
\text { matter (TOM) } \\
\text { decreasing (\%) }\end{array}$ \\
\hline A (BL536+BL542+BL548) & $12.23+10.49$ & $40.8 \pm 16^{\mathrm{bc}}$ & 59.2 \\
\hline B (PK446+BR883+BR931+M Y1112) & $17.92 \pm 5.97$ & $59.8 \pm 19.9^{d}$ & 40.2 \\
\hline C (MR55+BT950+BT951+PR1080+BN2067) & $13.08 \pm 2.46$ & $43.6 \pm 8.2^{c}$ & 56.4 \\
\hline$D(A+B)$ & $12.80 \pm 148$ & $42.7 \pm 4.9^{c}$ & 57.3 \\
\hline$E(A+C)$ & $8.82+130$ & $29.4 \pm 4.3^{\mathrm{abc}}$ & 70.6 \\
\hline$F(B+C)$ & $6.26 \pm 130$ & $20.9 \pm 4.3^{\mathrm{a}}$ & 79.1 \\
\hline$G(A+B+C)$ & $7.39 \pm 130$ & $24.7 \pm 14.3^{\mathrm{ab}}$ & 75.3 \\
\hline $\begin{array}{l}\text { H (Kontrol, tanpa probiotik) } \\
\text { (Without probiotic ) }\end{array}$ & $8.52 \pm 2.26$ & $38.5 \pm 10.2^{\mathrm{bc}}$ & 615 \\
\hline
\end{tabular}

* Angka dalam kolom yang sama yang diikuti huruf yang sama menunjukkan hasil yang tidak berbeda nyata $(P>0,05)$ (Values followed by the same superscripts are not significantly different $(P>0.05)$ ) 
udang windu, yaitu di bawah $30 \mathrm{mg} / \mathrm{L}$ (Madeali et al., 1997).

Kandungan amoniak $\left(\mathrm{NH}_{3}-\mathrm{N}\right)$ pada akhir penelitian dan penurunan kandungannya dibandingkan pada awal penelitian (rasio antara kandungan amoniak pada akhir penelitian dan awal penelitian, kemudian dikalikan 100\%) disajikan pada Tabel 2. Dari Tabel 2 tersebut terlihat, bahwa konsentrasi $\mathrm{NH}_{3}-\mathrm{N}$ pada semua perlakuan mengalami sedikit penurunan jika dibandingkan pada awal penelitian yaitu menurun antara $6,7 \%-56,4 \%$ dari kandungannya pada awal penelitian. Penurunan kandungan amoniak terbesar setelah pemberian probiotik selama 96 jam diperlihatkan pada perlakuan $\mathrm{D}$ (kombinasi antara bakteri probiotik asal laut dan mangrove) dan terendah pada perlakuan E (kombinasi antara bakteri probiotik asal laut dan tambak udang). Penggunaan bakteri yang berasal dari ekosistem yang berdekatan (laut dan mangrove), di mana di dalamnya terdapat jenis Pseudoalteromonas sp. Edeep-1 (dari laut) dan Kluyvera cryocrescens (dari mangrove) yang memiliki kemampuan dalam mengurai amoniak dalam perairan. Secara umum Atlas \& Bartha (1987) dalam Austin (1987) menyatakan, bahwa kandungan amoniak dalam perairan dipengaruhi secara langsung oleh adanya proses amonifikasi bahan organik dan protein yang ada dalam air dengan enzim urease yang dihasilkan oleh bakteri pengurai bahan organik menurut persamaan reaksi berikut:

$$
\mathrm{H}_{2} \mathrm{O}+\mathrm{NH}_{2} \cdot \mathrm{CO} \cdot \mathrm{NH}_{2} \rightarrow 2 \mathrm{NH}_{3}+\mathrm{CO}_{2}
$$

Jadi makin cepat reaksi di atas, maka kandungan amoniak dalam air media akan semakin tinggi. Sedangkan penurunannya terjadi apabila proses tersebut berlanjut ke proses nitrifikasi oleh adanya bakteri Nitrosomonas spp. dan Nitrobacter spp. dalam air media pemeliharaan yang cukup oksigen.

Secara keseluruhan, kandungan amoniak $\left(\mathrm{NH}_{3}-\mathrm{N}\right)$ dalam media pemeliharaan pascalarva udang windu pada akhir penelitian ini $(0,287-$ $0,697 \mathrm{mg} / \mathrm{L}$ ) tergolong kurang aman, karena kandungan yang aman untuk larva udang windu menurut Chin \& Chen (1987) adalah lebih rendah dari 0,13 mg/L. Walaupun demikian, kandungan amoniak di atas masih jauh di bawah nilai LC $_{50} 96$ jam untuk udang windu (1,26 mg/L) (Chin \& Chen, 1987). Mengingat bahwa penelitian ini hanya berlangsung selama 96 jam, maka kandungan amoniak dalam penelitian ini masih cukup aman untuk pemeliharaan pascalarva udang windu. Untuk pemeliharaan pascalarva udang windu pada waktu yang lebih lama lagi disarankan untuk melakukan penggantian air apabila kandungan amoniak telah melebihi batas yang kurang aman $(0,13 \mathrm{mg} / \mathrm{L})$, karena konsentrasi

Tabel 2. Perbaikan kandungan amoniak $\left(\mathrm{NH}_{3}-\mathrm{N}\right)$ dalam air media pemeliharaan pascalarva udang windu setelah 96 jam penggunaan komposisi bakteri probiotik berbeda

Table 2. Improvement of ammonia concentration in tiger shrimp postlarvae culture media after 96 hour application of different composition of probiotic bacteria

\begin{tabular}{|c|c|c|c|c|}
\hline & $\begin{array}{c}\text { Komposisi bakteri probiotik } \\
\text { Probiotic bacteria compositions }\end{array}$ & $\begin{array}{l}\text { Kandungan } \mathrm{NH}_{3}-\mathrm{N} \\
\text { pada akhir penelitian } \\
\text { Final concentration } \\
\text { of ammonia ( } \mathrm{mg} / \mathrm{L})\end{array}$ & $\begin{array}{c}\text { Persentase } \mathrm{NH}_{3}-\mathrm{N} \\
\text { dibanding awal } \\
\text { Percentage of final to } \\
\text { initial } \mathrm{NH}-\mathrm{N} \\
(\%)^{*}\end{array}$ & $\begin{array}{c}\text { Penurunan } \\
\mathrm{NH}_{3}-\mathrm{N} \\
\mathrm{NH}_{3}-\mathrm{N} \\
\text { decreasing } \\
\text { (\%) }\end{array}$ \\
\hline A & (B L536+B L542+B L548) & $0.358 \pm 0.035$ & $49.0 \pm 4.8^{\mathrm{a}}$ & 510 \\
\hline B & (P K446+B R883+BR931+M Y1112) & $0.352 \pm 0.085$ & $48.2+117^{a}$ & 518 \\
\hline C & (M R55+B T950+B T951+P R1080+B N2067) & $0.650 \pm 0.063$ & $89.0 \pm 8.6^{\mathrm{b}}$ & 10 \\
\hline D & $(A+B)$ & $0.319 \pm 0.027$ & $43.6 \pm 3.7^{\mathrm{a}}$ & 56.4 \\
\hline$E$ & $(A+C)$ & $0.697 \pm 0.038$ & $95.3 \pm 5.2^{\mathrm{b}}$ & 4.7 \\
\hline $\mathrm{F}$ & $(B+C)$ & $0.682 \pm 0.049$ & $93.3 \pm 6.8^{\mathrm{b}}$ & 6.7 \\
\hline G & $(A+B+C)$ & $0.662 \pm 0.048$ & $90.5 \pm 6.5^{b}$ & 9.5 \\
\hline $\mathrm{H}$ & $\begin{array}{l}\text { (Kontrol, tanpa probiotik) } \\
\text { (Without probiotic ) }\end{array}$ & $0.287 \pm 0.054$ & $90.1+16.9^{b}$ & 9.9 \\
\hline
\end{tabular}

Angka dalam kolom yang sama yang diikuti huruf yang sama menunjukkan hasil yang tidak berbeda nyata $(P>0,05)$. Data sebelum dianalisis diubah ke persentase (Values followed by the same superscripts are not significantly different $(P>0.05)$. Data were transformed to arcsin V-percentage before analysed for differences) 
amoniak yang tinggi dalam waktu yang lama dapat mengakibatkan udang mudah mengalami stres dan terserang penyakit.

Tabel 3 memperlihatkan, bahwa konsentrasi nitrit $\left(\mathrm{NO}_{2}-\mathrm{N}\right)$ pada akhir penelitian untuk semua perlakuan tidak mengalami perubahan (peningkatan atau penurunan) yang berarti dibandingkan konsentrasinya pada awal penelitian, yaitu antara 99,4\%$153,6 \%$ dari konsentrasinya pada awal penelitian. Secara keseluruhan sebenarnya konsentrasi nitrit dalam media air pemeliharaan pascalarva udang windu cenderung mengalami peningkatan dibandingkan konsentrasi awalnya, kecuali pada perlakuan kombinasi bakteri probiotik asal tambak (MR55+BT950+BT951+PR1080+BN2067) yang relatif tetap $(99,4 \%)$. Hal ini diduga karena adanya bakteri pengurai nitrit dalam air tambak yang digunakan sebagai media pemeliharaan pascalarva udang windu pada penelitian ini. Terjadinya sedikit peningkatan kandungan nitrit $(113,6 \%-153,4 \%)$ pada perlakuan penggunaan bakteri probiotik diduga karena adanya masukan unsur nitrogen yang berasal dari nutrient broth yang digunakan sebagai media perbanyakan bakteri probiotik. Selain itu, adanya proses oksidasi amoniak (hasil ekskresi udang windu) dengan adanya aerasi yang cukup, serta ketersediaan bakteri nitrifikasi dalam air seperti Nitrosomonas spp. dan Nitrosococcus spp. (Austin, 1987) juga dapat menyebabkan peningkatan kandungan nitrit dalam media pemeliharaan pascalarva udang windu. Secara umum kisaran kandungan nitrit pada akhir penelitian pada semua perlakuan $(0,0136-0,0184 \mathrm{mg} / \mathrm{L}) \mathrm{masih}$ tergolong sangat rendah. Dalam hal ini Chen \& Chin (1988) merekomendasikan, bahwa konsentrasi nitrit yang aman untuk pemeliharaan pascalarva udang windu adalah lebih rendah dari $4,5 \mathrm{mg} / \mathrm{L}$. Dengan demikian dapat dikatakan, bahwa kandungan nitrit dalam penelitian ini masih sangat aman untuk pemeliharaan pascalarva udang windu dan bukan merupakan penyebab kematian pascalarva udang windu yang mungkin terjadi selama peneitian berlangsung. Kandungan nitrit yang relatif rendah dalam penelitian ini dimungkinkan, karena adanya proses nitrifikasi lanjutan oleh adanya bakteri Nitrobacter spp. dalam air tambak yang digunakan untuk pemeliharaan pascalarva udang windu yang dibantu oleh kecukupan oksigen dalam air akibat aerasi secara terus-menerus. Boyd (1990) menuliskan reaksi kimia perubahan nitrogen dalam bentuk amoniak ke bentuk nitrit dan nitrat sebagai berikut:

$$
\begin{aligned}
& \mathrm{NH}_{3}+\mathrm{H}^{+} \longrightarrow \mathrm{NH}_{4}^{+} \\
& \mathrm{NH}_{4}^{+}+1.5 \mathrm{O}_{2} \longrightarrow \mathrm{NO}_{2}{ }^{+}+2 \mathrm{H}^{+}+\mathrm{H}_{2} \mathrm{O} \\
& \mathrm{NO}_{2}+0.5 \mathrm{O}_{2} \longrightarrow \mathrm{NO}_{3}^{-}
\end{aligned}
$$

Tabel 3. Perubahan kandungan nitrit $\left(\mathrm{NO}_{2}-\mathrm{N}\right)$ dalam air media pemeliharaan pascalarva udang windu setelah 96 jam penggunaan komposisi bakteri probiotik berbeda

Table 3. Variation of nitrite $\left(\mathrm{NO}_{2}-\mathrm{N}\right)$ concentrations in tiger shrimp postlarvae

\begin{tabular}{|c|c|c|}
\hline $\begin{array}{c}\text { Komposisi bakteri probiotik } \\
\text { Probiotic bacteria compositions }\end{array}$ & $\begin{array}{c}\text { Kandungan nitrit pada } \\
\text { akhir penelitian } \\
\text { Final concentration } \\
\text { of nitrite }\left(\mathrm{NO}_{2}-\mathrm{N}\right) \\
(\mathrm{mg} / \mathrm{L})\end{array}$ & $\begin{array}{c}\text { Persentase nitrit } \\
\text { dibanding awal } \\
\text { Percentage of final } \\
\text { to initial } \mathrm{NO}_{2}-\mathrm{N} \\
(\%)^{*}\end{array}$ \\
\hline A (BL536+B L542+BL548) & $0.0147 \pm 10.0019$ & $122.2 \pm 16.2^{\mathrm{a}}$ \\
\hline B (PK446+B R883+BR931+M Y1112) & $0.0136 \pm 0.0022$ & $113.6 \pm 18.4^{a}$ \\
\hline C (M R55+BT950+B T951+PR1080+BN2067) & $0.0119 \pm 0.0008$ & $99.4 \pm 6.9^{a}$ \\
\hline$D(A+B)$ & 0.01510 .0049 & $125.8 \pm 40.9^{a}$ \\
\hline$E(A+C)$ & $0.0136 \pm 0.0014$ & $113.6 \pm 112^{\mathrm{a}}$ \\
\hline$F(B+C)$ & $0.0158 \pm 0.0051$ & $1317 \pm 42.7^{a}$ \\
\hline$G(A+B+C)$ & $0.0184 \pm 0.0072$ & $153.6 \pm 60.2^{\mathrm{a}}$ \\
\hline H (Kontrol, tanpa probiotik) (Without probiotic ) & $0.0158 \pm 0.0031$ & $1317 \pm 25.4^{\mathrm{a}}$ \\
\hline
\end{tabular}
culture media after 96 hour application of different compositions of probiotic bacteria

Angka dalam kolom yang sama yang diikuti huruf yang sama menunjukkan hasil yang tidak berbeda nyata $(P>0,05)$. Data sebelum dianalisis diubah ke persentase (Values followed by the same superscripts are not significantly different $(P>0.05)$. Data were transformed to arcsin $V$ percentage before analysed for differences) 
Berdasarkan reaksi kimia di atas, jelas bahwa perubahan amoniak menjadi nitrit dan nitrat selain dipengaruhi oleh adanya bakteri nitrifikasi, juga sangat dipengaruhi oleh kecukupan oksigen dalam air (Dissolved Oxygen $=\mathrm{O}_{2}$ terlarut). Oleh karena itu, wajar bila kandungan nitrit dalam penelitian ini sangat rendah, karena air media yang digunakan adalah air tambak yang mengandung bakteri nitrifikasi dan selama pemeliharaan selalu mendapatkan penambahan oksigen melalui aerasi secara terus-menerus.

Pada Tabel 4 terlihat, bahwa sintasan pascalarva udang windu tertinggi pada perlakuan yang menggunakan kombinasi bakteri BL536, BL542, BL548 (perlakuan A, bakteri asal laut), kemudian disusul dengan perlakuan yang menggunakan kombinasi bakteri MY1112, BR931, BR883, PK446, MR55, BT950, BT951, PR1080, dan BN2067 (perlakuan $\mathrm{F}$, kombinasi bakteri asal mangrove dan tambak). Sedangkan sintasan pascalarva udang windu terendah pada kontrol (tanpa penggunaan probiotik).

Hasil analisis statistik menunjukkan, bahwa tidak ada perbedaan yang nyata $(P>0,05)$ antar sintasan pascalarva udang windu pada semua perlakuan yang menggunakan probiotik, kecuali penggunaan kombinasi bakteri probiotik asal laut BL536, BL542, dan BL548 (perlakuan $A=97,5 \%$ ) yang nyata lebih tinggi $(P<0,05)$ daripada kontrol (tanpa probiotik $=82,0 \%$ ). Hal ini menunjukkan, bahwa penggunaan kombinasi tiga jenis bakteri laut tersebut dapat mencegah kematian pascalarva udang windu lebih baik dibandingkan dengan kontrol. Dari hasil skrining sebelumnya, ketiga jenis bakteri tersebut berasal dari laut dan telah terbukti dapat menghambat pertumbuhan Vibrio harveyi baik secara "in-vitro" maupun "in-vivo" (Muliani et al., 2003). Dengan demikian, tingginya sintasan pascalarva udang windu pada perlakuan kombinasi bakteri asal laut, karena kemampuan bakteri tersebut dalam menekan perkembangbiakan bakteri Vibrio spp. dalam air media pemeliharaan udang.

Berdasarkan analisis regresi didapatkan, bahwa sintasan pascalarva udang windu berbanding terbalik dengan kandungan total Vibrio spp. dalam air media pemeliharaan pada akhir penelitian $(r=-0,834 ; P<0,01)$. Hal ini menunjukkan, bahwa penggunaan bakteri probiotik (terutama yang berasal dari laut) dapat menekan perkembangbiakan bakteri Vibrio spp. hingga di bawah korum sensingnya, sehingga secara tak langsung dapat menekan kematian pascalarva udang windu. Kepadatan bakteri Vibrio spp. pada akhir penelitian pada perlakuan A (bakteri probiotik asal laut) didapatkan jumlahnya $8,71 \times 10^{2} \mathrm{CFU} /$ $\mathrm{mL}$, sedangkan pada kontrol (tanpa bakteri probiotik) jumlahnya $3,39 \times 10^{3} \mathrm{CFU} / \mathrm{mL}$. Dengan demikian dapat dikatakan, bahwa Vibrio spp. memang merupakan salah satu penyebab kematian pascalarva udang windu

Tabel 4. Sintasan pascalarva udang windu setelah 96 jam penggunaan komposisi bakteri probiotik berbeda

Table 4. Survival rate of tiger shrimp postlarvae after 96-h application of different compositions of probiotic bacteria

\begin{tabular}{lc}
\hline $\begin{array}{c}\text { Komposisi bakt eri probiotik } \\
\text { Probiotic bacteria compositions }\end{array}$ & $\begin{array}{c}\text { Sintasan udang windu } \\
\text { Survival rate of tiger shrimp (\%) }\end{array}$ \\
\hline A (BL536+BL542+BL548) & $97.5^{\mathrm{a}}$ \\
B (PK446+BR883+BR931+MY1112) & $95.2^{\mathrm{ab}}$ \\
C (MR55+BT950+BT951+PR1 080+BN2067) & $94.0^{\mathrm{ab}}$ \\
D (A+B) & $88.7^{\mathrm{ab}}$ \\
E (A+C) & $85.7^{\mathrm{ab}}$ \\
F (B+C) & $94.7^{\mathrm{ab}}$ \\
G (A+B+C) & $85.5^{\mathrm{ab}}$ \\
H (Kontrol, tanpa probiotik) (Without & $82.0^{\mathrm{b}}$ \\
& \\
\hline
\end{tabular}

Angka dalam kolom yang sama yang diikuti huruf yang sama menunjukkan hasil yang tidak berbeda nyata $(P>0,05)$ (Values followed by the same superscripts are not significantly different $(P>0.05))$ 


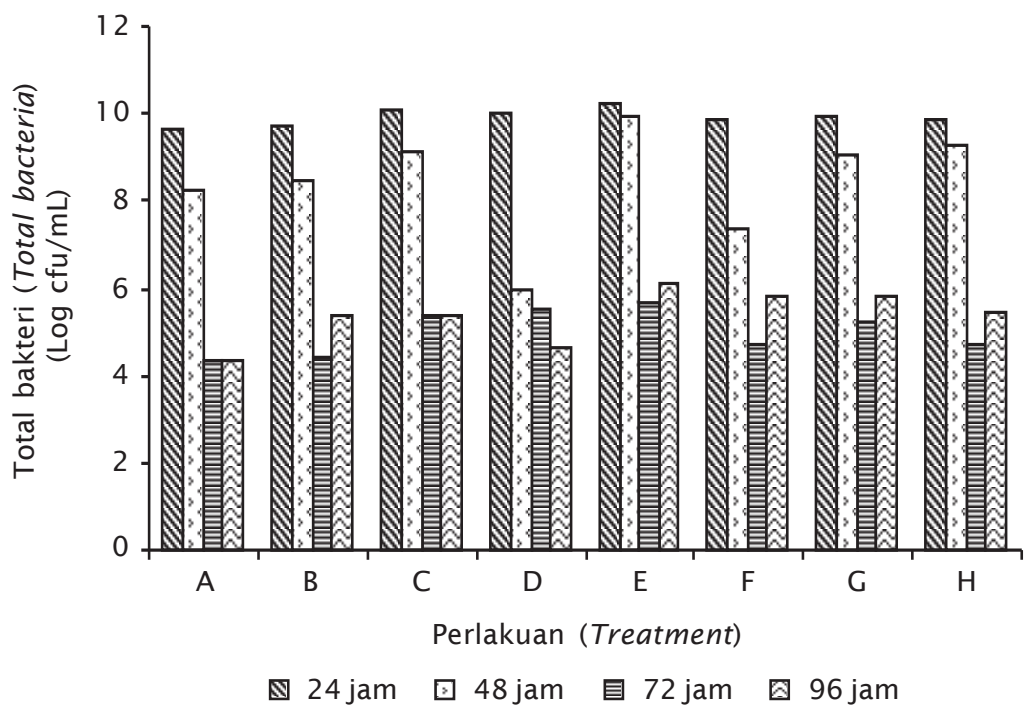

(A) = bakteri laut; $(B)=$ bakteri mangrove; $(C)$ = bakteri tambak; $(D)$ = bakteri laut+bakteri mangrove; $(\mathrm{E})$ = bakteri laut+bakteri tambak; $(\mathrm{F})$ = bakteri mangrove+bakteri tambak; $(G)$ = bakteri laut+bakteri magrove+bakteri tambak; $(\mathrm{H})=$ kontrol (tanpa pemberian bakteri probiotik)

Gambar 1. Total bakteri dalam air media pemeliharaan pascalarva udang windu selama penelitian aplikasi bakteri probiotik dengan komposisi berbeda

Figure 1. Total bacterial count in tiger shrimp postlarvae culture media during application of different compositions of probiotic bacteria

dalam penelitian ini. Dalam hal ini Prayitno (1994) melaporkan, bahwa V. harveyi dapat menyebabkan kematian pada larva udang windu apabila kandungannya mencapai $10^{3}$ $\mathrm{CFU} / \mathrm{mL}$. Atmomarsono et al., 1993 juga melaporkan, bahwa berbagai kasus vibriosis pada budidaya udang windu di tambak terjadi pada saat kandungan total vibrio dalam air tambak di atas $1,0 \times 10^{3} \mathrm{CFU} / \mathrm{mL}$.

Sedangkan Panjaitan (1991) mendapatkan, bahwa peningkatan bahan organik total dalam air merupakan pemicu perkembangbiakan bakteri Vibrio spp. Oleh karena itu, aplikasi bakteri probiotik yang memiliki kemampuan menguraikan bahan organik seperti bakteri Bacillus spp. (termasuk $B$. firmus dalam penelitian ini) dan Pseudoalteromonas sp. (salah satu bakteri asal laut) akan dapat menekan perkembangbiakan $V$. harveyi dalam air media pemeliharaan udang. Hasil pengamatan terhadap perkembangan populasi total bakteri dan total Vibrio spp. disajikan pada Gambar 1 dan 2.

Dari Gambar 1 terlihat, bahwa total bakteri dalam air media pemeliharaan pascalarva udang windu cenderung mengalami penurunan dari pengamatan 24 jam hingga 96 jam. Total bakteri pada 24 jam pertama berkisar antara $4,47 \times 10^{9}-1,58 \times 10^{10} \mathrm{CFU} / \mathrm{mL}$ menjadi $8,71 \times 10^{5}-8,13 \times 10^{9} \mathrm{CFU} / \mathrm{mL}$ setelah $48 \mathrm{jam}$, dan turun lagi antara $2,04 \times 10^{4}-6,76 \times 10^{5} \mathrm{CFU} /$ $\mathrm{mL}$ setelah 96 jam. Penurunan jumlah total bakteri dalam air media pemeliharaan adalah sesuatu yang sifatnya alamiah, karena jumlahnya yang cukup tinggi. Pada dasarnya jumlah bakteri total di perairan yang tidak tercemar adalah sekitar $1,0 \times 10^{6}$ hingga $10^{8}$ $\mathrm{CFU} / \mathrm{mL}$ (Atmomarsono, 2000). Peningkatan atau penurunan jumlah dan jenis bakteri yang ada sangat dipengaruhi oleh jumlah dan jenis cemaran yang ada, serta kondisi kualitas airnya $(\mathrm{pH}$, alkalinitas total, dan kecukupan oksigen terlarut). Oleh karena itu, dalam aplikasi bakteri probiotik di tambak udang nantinya harus selalu diperhitungkan kapan bakteri tersebut harus ditambahkan lagi agar jumlahnya cukup memadai untuk membantu mempercepat proses penguraian bahan organik yang ada. Dalam penelitian ini tidak dilakukan penambahan bakteri lagi, karena pengujian hanya dilakukan selama 96 jam. 


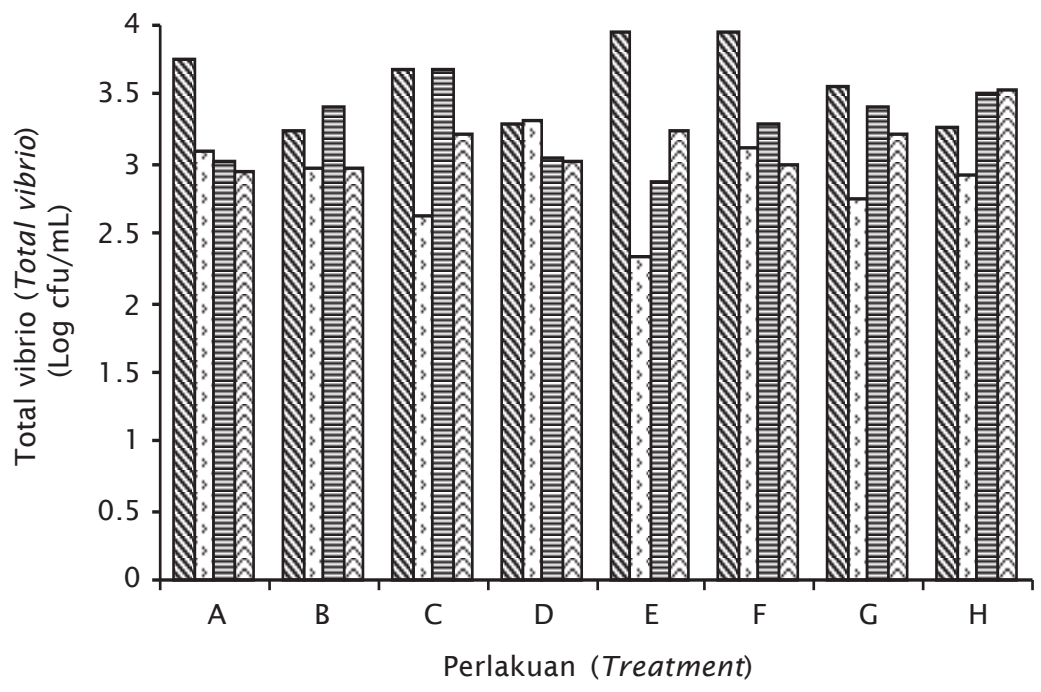

图 $24 \mathrm{jam}$ 口 $48 \mathrm{jam}$ 目 $72 \mathrm{jam}$ 因 $96 \mathrm{jam}$

(A) = bakteri laut; $(\mathrm{B})$ = bakteri mangrove; $(\mathrm{C})$ = bakteri tambak; $(\mathrm{D})$ = bakteri laut+bakteri mangrove; $(\mathrm{E})$ = bakteri laut+bakteri tambak; $(\mathrm{F})$ = bakteri mangrove+bakteri tambak; $(G)$ = bakteri laut+bakteri magrove+bakteri tambak; $(\mathrm{H})=$ kontrol (tanpa pemberian bakteri probiotik)

Gambar 2. Total Vibrio spp. dalam air media pemeliharaan pascalarva udang windu selama penelitian aplikasi bakteri probiotik dengan komposisi berbeda

Figure 2. Total vibrio count in tiger shrimp postlarvae culture media during application of different compositions of probiotic bacteria

Pada Gambar 2 terlihat, bahwa jumlah bakteri Vibrio spp. pada perlakuan dengan menggunakan probiotik asal laut (perlakuan A) juga semakin menurun dari waktu ke waktu, yaitu $5,62 \times 10^{3} \mathrm{CFU} / \mathrm{mL}$, pada 24 jam pertama menurun menjadi $1,26 \times 10^{3} \mathrm{CFU} / \mathrm{mL}$ pada 48 jam, kemudian menjadi $1,07 \times 10^{3} \mathrm{CFU} / \mathrm{mL}$ pada 72 jam, dan menjadi $8,71 \times 10^{2} \mathrm{CFU} / \mathrm{mL}$ setelah 96 jam. Hal ini menunjukkan, bahwa bakteri probiotik asal laut mampu bekerja menekan perkembangbiakan bakteri $V$. harveyi dalam air media pemeliharaan udang. Sedangkan pada kontrol (tanpa bakteri probiotik), jumlah bakteri vibrionya justru cenderung naik dari waktu ke waktu, yaitu dari $1,58 \times 10^{3} \mathrm{CFU} / \mathrm{mL}$ pada 24 jam menjadi $8,13 \times 10^{2} \mathrm{CFU} / \mathrm{mL}$ pada $48 \mathrm{jam}$, namun naik kembali menjadi $3,31 \times 10^{3} \mathrm{CFU} /$ $\mathrm{mL}$ pada 72 jam dan $3,39 \times 10^{3} \mathrm{CFU} / \mathrm{mL}$ setelah 96 jam. Kandungan bakteri Vibrio spp. pada kontrol yang selalu di atas $1,0 \times 10^{3} \mathrm{CFU} / \mathrm{mL}$ dapat menyebabkan terjadinya vibriosis dan kematian pada pascalarva udang windu yang dipelihara. Oleh karena itu, aplikasi bakteri probiotik mutlak diperlukan dalam pemeliharaan pascalarva udang windu untuk mencegah perkembangbiakan bakteri Vibrio spp. (termasuk $V$. harveyi yang mematikan tersebut). Bakteri $V$. harveyi yang dikenal di masyarakat sebagai bakteri kunang-kunang diduga baru mencapai korum sensing untuk menyerang pascalarva udang windu apabila jumlahnya telah mencapai $1,0 \times 10^{3} \mathrm{CFU} / \mathrm{mL}$. Hal ini sesuai dengan yang dilaporkan oleh Atmomarsono et al. (1993).

\section{KESIMPULAN DAN SARAN}

1. Penggunaan bakteri probiotik asal tambak dan mangrove dapat mengendalikan kandungan bahan organik secara signifikan $(\mathrm{P}<0,05)$.

2. Bakteri probiotik asal laut dan mangrove secara tunggal maupun kombinasinya dapat menekan peningkatan amoniak dalam air media pemeliharaan pascalarva udang windu $(P<0,05)$.

3. Bakteri probiotik tidak mampu menekan peningkatan kandungan nitrit dalam air media pemeliharaan udang $(P>0,05)$, namun konsentrasinya masih aman. 
4. Bakteri probiotik asal laut dapat menekan kematian pascalarva udang windu melalui pengendalian perkembangbiakan bakteri Vibrio spp. dalam air.

5. Untuk mengetahui efektifitas penggunaan bakteri probiotik terhadap sintasan dan pertumbuhan udang windu disarankan untuk melanjutkan penelitian ini dalam jangka waktu yang lebih lama.

6. Penelitian tentang penggunaan bakteri probiotik pada tingkat teknologi budidaya udang berbeda masih diperlukan.

\section{DAFTAR ACUAN}

Albaladejo, J.D., Tapay, L.M., Migo, V.P., Alfafara, C.G., Somga, S.L., Mayo, S.L., Miranda, R.C., Natividal, K., Mogbanua, F.O., Itami, T., Matsumura, M., \& Nadala. E.C.B. 1998. Screening for shrimp viruses in the Philippines In Flegel, T.W. (Ed.). Advances in shrimp biotechnology. National Center for Genetic Engineering and Biotechnology, Bangkok, Thailand, p. 252-253.

Atmomarsono, M. 1992. Faktor penduga kesuburan tambak tradisional. J. Penel. Budidaya Pantai, 8(4): 73-85.

Atmomarsono, M. 2000. Teknologi budidaya udang windu berkelanjutan. Dalam Nessa, M.N., Bengen, D.G., Ali, S.A., Djawad, M. I., Budimawan (Eds). Prosiding Konferensi Nasional II, Pengelolaan Sumberdaya Pesisir dan Lautan Indonesia, Hotel Sahid, Makassar, 15-17 Mei 2000, hlm. G64G72.

Atmomarsono, M. 2004. Pengelolaan kesehatan udang windu, Penaeus monodon di tambak. Aquacultura Indonesiana, 5(2): 73-78.

Atmomarsono, M., Madeali, M.I., Muliani, \& Tompo, A. 1993. Kasus penyakit udang windu di Kabupaten Pinrang. Dalam Hanafi, A., Atmomarsono, M., Ismawati, S. (Eds.). Prosiding Seminar Hasil Penelitian Perikanan Budidaya Pantai, Maros, 16-19 Juli 1993, hlm. 35-40.

Atmomarsono, M., Muliani, \& Ismawati, S. 1995. Prospek penggunaan tandon pada budidaya udang windu. Makalah disajikan pada Ekspose Hasil Penelitian di Instalasi Pengkajian Teknologi Pertanian Wonocolo, Surabaya, 2-4 Juli 1995, $10 \mathrm{hlm}$.

Austin, B. 1987. Marine microbiology. Cambridge University Press. Cambridge, 222 pp.

Boyd, C.E., 1990. Water Quality in Ponds for Aquaculture. Birmingham Publishing Co, Birmingham, Alabama, USA, 482 pp.
Chanratchakool, P., Turnbull, J.F., Smith, S.F., \& Limsuwan, C. 1995. Health Management in Shrimp Ponds. Second Edition. Aquatic Animal Health Research Institute. Dept. of Fisheries. Kasetsart Univeristy Campus. Bangkok, $111 \mathrm{pp}$.

Chen, J.C. \& Chin, T.C. 1988. Acute toxixity of nitrite to tiger prawn, Penaeus monodon larvae. Aquaculture, 69: 253-262.

Chin, T.S. \& Chen, J.C. 1987. Acute toxicity of ammonia to larvae of the tiger prawn, Penaeus monodon. Aquaculture, 66: 247253.

Dhar, A.K., Roux, M.M., \& Klimpel, K.R. 2001. Detection and quantification of infectious hypodermal and hematopoietic necrosis virus and white spot syndrome virus in shrimp using Real-Time quantitative PCR and SYBR green chemistry. Journal of Clinical Microbiology, 39: 2,835-2,845.

Hala, Y. 1999. Penggunaan gen penanda molekuler untuk deteksi pelekatan dan kolonisasi Vibrio harveyi pada larva udang windu (Penaeus monodon). Disertasi Program Pascalarva IPB, Bogor, 91 hlm.

Haryanti, Sugama, K., Tsumura, S., \& Nishijima, T. 2000. Vibriostatic bacterium isolated from seawater: Potentiality as probiotic agent in the rearing of Penaeus monodon larvae. Ind. Fish. Res. J., 6: 26-32.

Itami, T., Maeda, M., Suzuki, N., Tokushige, K., Nakagawa, A., Henning, O., Kondo, M., Kasornchandra, J., Hirono, L., Aoki, T., Kusuda, \& Takahashi, Y. 1998. Possible prevention of White Spot Syndrome Virus (WSSV) in kuruma shrimp, Penaeus japonicus, in Japan. In Flegel, T.W. (Ed.). Advances in shrimp biotechnology. National Center for Genetic Engineering and Biotechnology, Bangkok, p. 291-295.

Kono, T., Savan, R., \& Itami, T. 2004. Detection of white spot syndrome virus in shrimp by Loop-mediated isothermal amplification. J. Virol. Methods, 115: 59-65.

Lo, C.F., Wang, C.H., \& Kou, G.H. 1997. White spot. syndrome (WSS): Pathology, hosts, and prevalence in captured shrimp and crabs in Taiwan. In Inui, Y. (Ed.). NRIA International workshop. New approaches to viral diseases of aquatic animals. NRIA Nansei. Watarai, Mie, Japan, p. 206-217.

Madeali, M.I., Atmomarsono, M., Muliani, \& Tompo, A. 1997. Pengaruh konsentrasi BOT terhadap patogenesitas bakteri Vibrio sp. 
pada udang windu. Laporan Hasil Penelitian Perikanan Pantai, Maros, $12 \mathrm{hlm}$.

Madeali, M.I., Atmomarsono, M., Tompo, A., \& Muliani. 1993. Studi kasus penyebab kematian udang windu Penaeus monodon di tambak intensif. J. Pen. Budidaya Pantai, 9(4): 23-28.

Muliani, Atmomarsono, M., \& Madeali, M.I. 1998. Pengaruh penggunaan kekerangan sebagai biofilter terhadap kelimpahan dan komposisi jenis bakteri pada budidaya udang windu (Penaeus monodon) dengan sistem resirkulasi air. J. Pen. Perik. Indonesia, 3: 54-61.

Muliani, Tampangallo, B.R., Nurbaya, \& Kadriah, I.A.K. 2003. Penyebaran bakteri Vibrio sp. resisten antibiotik di pertambakan Sulawesi Selatan. Laporan Hasil Penelitian Balai Riset Perikanan Budidaya Air Payau, Maros, $14 \mathrm{hlm}$.

Muliani, Nurbaya, Tompo, A., \& Atmomarsono, M. 2004. Eksplorasi bakteri filosfer dari tanaman mangrove sebagai bakteri probiotik pada budidaya udang windu, Penaeus monodon. J. Pen. Perik. Indonesia, 10(2): 47-57.

Panjaitan, P.J. 1991. Serangan penyakit kunangkunang pada larva udang windu (Penaeus monodon Fabricus) di panti benih daerah Situbondo, Jawa Timur. Tesis Magister Sain. Program Studi Ilmu Perairan Fakultas Pascasarjana, IPB. Bogor, $99 \mathrm{hlm}$.

Poernomo, A. 2004. Technology of probiotics to solve the problems in shrimp pond culture and the culture environment. Paper presented in The National Symposium on Development and Scientific and Technology Innovation in Aquaculture, January 2729, 2005, Patrajasa Hotel, Semarang, 25 pp.
Prayitno, S.B. 1994. Studies of bacteria causing prawn disease in Indonesia with special emphasis on Luminous bacterial disease. PhD Thesis. School of Ocean Sciences. University of Norths Wales, Bangor, UK, $250 \mathrm{pp}$.

Rengpipat, S., Rukpratanporn, S. Piyatiratitivorakul, S., \& Menasveta, P. 1998. Probiotics in Aquaculture: A case study of probiotics for larvae of black tiger shrimp (Penaeus monodon). In Flegel, T.W. (Ed). Advances in shrimp biotechnology. National Center for Genetic Engineering and Biotechnology, Bangkok, p. 177-181.

Rosa, D., Zafran, Taufik, I., \& Girsang, M.A. 1997. Pengendalian Vibrio harveyi secara biologis pada larva udang windu (Penaeus monodon): I. Isolasi Bakteri Penghambat. J. Pen. Perik. Indonesia, 3: 1-10.

Spann, K.M., Vickers, J.E., \& Lester, R.J.G. 1995. Lymphoid organ virus of Penaeus monodon from Australia. Dis. Aquat. Org., 23: 127134.

Steel, R.G.D. \& Torrie, J.H. 1995. Prinsip dan Prosedur Statistika, Suatu Pendekatan Biometri. Alih bahasa oleh Bambang Sumantri. Cetakan IV. Penerbit PT Gramedia Pustaka Utama. Jakarta, 772 hlm.

Tjahyadi, M.R., Angka, S.L., \& Suwanto, A. 1994. Isolation and evaluation of marine bacteria for biocontrol of luminous bacterial diseases in tiger shrimp larvae (Penaeus monodon Fab.). Aspac. J. Mol. Biol. Biotechnol, 2: 347-352.

Vaseeharan, B., Jayakumar, R., \& Ramasamy, P. 2003. PCR-base detection of white spot syndrome virus in cultured and captured crustaceans in India. Lett. Appl. Microbiol., 37: 443-447. 